\title{
UJI KESUKAAN HASIL JADI KUE BROWNIES MENGGUNAKAN TEPUNG TERIGU DAN TEPUNG GANDUM UTUH
}

\author{
Dianka Wahyuningtias; Trias Septyoari Putranto; \\ Raden Nana Kusdiana
}

\author{
Hotel Management Department, Faculty of Economic and Communication, BINUS University \\ Jln. K.H. Syahdan No. 9, Palmerah, Jakarta Barat 11480 \\ dwahyuningtias@binus.edu
}

\begin{abstract}
The purpose of this research is to discover the degree of preferences in flavor, aroma, color, shape, and texture in the Brownies using 100\% whole grain flour and to discover the public acceptability to the Brownies using 100\% whole wheat flour. The research is using Experimental Research. The research is using a descriptive statistical analysis method that is used to analyze data in ways that describe or depict the data that has been collected. The results showed that the average yield of the Brownies using $100 \%$ whole grain flour is higher than Brownies with wheat flour. On the basis of these results, it can be concluded that people prefer like Brownies using whole grain flour instead of Brownies using wheat flour.
\end{abstract}

Keywords: brownies, whole wheat flour, experimental research

\begin{abstract}
ABSTRAK
Tujuan penelitian ini adalah untuk mengetahui tingkat kesukaan rasa, aroma, warna, dan tekstur pada hasil jadi Brownies yang menggunakan tepung gandum utuh 100\% dan mengetahui daya terima masyarakat terhadap hasil jadi Brownies yang menggunakan tepung gandum utuh 100\%. Penelitian ini dilakukan dengan cara penelitian eksperimental. Metode penelitian yang digunakan adalah metode analisis statistik deskriptif yang digunakan untuk menganalisa data dengan cara mendeskripsikan atau menggambarkan data yang telah terkumpul. Hasil penelitian, menunjukkan bahwa hasil rata-rata Brownies sdengan tepung gandum utuh lebih tinggi daripada Brownies dengan tepung terigu. Dengan didasarkan pada hasil tersebut, dapat disimpulkan bahwa masyarakat lebih menyukai Brownies yang menggunakan tepung gandum utuh daripada Brownies dengan tepung terigu.
\end{abstract}

Kata kunci: brownies, tepung gandum utuh, penelitian eksperimental 


\section{PENDAHULUAN}

Pada saat ini, salah satu industri yang berkembang sangat pesat adalah industri kuliner atau makanan. Salah satu makanan yang sedang digemari oleh masyarakat adalah aneka jenis kue, hal ini dikarenakan oleh banyak variasi kue dan roti yang sudah beredar di berbagai toko penjual aneka macam kue dan roti. Salah satu jenis kue yang paling banyak diminati oleh masyarakat dan mudah ditemui adalah kue brownies. Brownies merupakan kue yang berbahan dasar coklat yang telah banyak beredar dan dijual di berbagai toko kue dan roti karena digemari oleh banyak orang. Brownies biasanya terbuat dari campuran bahan adonan seperti tepung terigu, cokelat masak, cokelat bubuk, telur, dan gula. Brownies merupakan kue bolu cokelat yang tidak diberi bahan pengembang atau baking powder dan dibuat dengan proses pemanggangan.

Salah satu bahan Brownies adalah tepung terigu yang merupakan salah satu bahan dasar untuk pembuatan kue dan roti. Pada jaman sekarang terdapat aneka macam kue dan roti dengan bahan pengganti tepung terigu, seperti tepung ubi merah, tepung kacang, dan lain-lain. Roti gandum merupakan roti yang terbuat dari tepung gandum utuh. Roti atau kue dengan berbahan dasar tepung gandum utuh merupakan makanan yang dianggap lebih sehat dan berserat dibandingkan dengan berbahan dasar tepung terigu yang biasa digunakan.

Berdasarkan latar belakang diatas penulis tertarik untuk melakukan eksperimen membuat brownies dengan mengganti tepung terigu dengan tepung gandum utuh atau Whole Wheat Flour.

\section{Rumusan Masalah}

Masalah yang akan diulas dalam penelitian ini adalah (1) Bagaimana tingkat kesukaan rasa, aroma, warna dan tekstur pada hasil jadi brownies yang menggunakan tepung gandum utuh $100 \%$ ? (2) Bagaimana daya terima masyarakat terhadap hasil jadi brownies yang menggunakan tepung gandum utuh $100 \%$ ?

\section{Tujuan Penelitian}

Penelitian ini bertujuan untuk (1) Mengetahui tingkat kesukaan rasa, aroma, warna, dan tekstur pada hasil jadi brownies yang menggunakan tepung gandum utuh 100\%. (2) Mengetahui daya terima masyarakat terhadap hasil jadi brownies yang menggunakan tepung gandum utuh $100 \%$.

\section{Manfaat Penelitian}

Manfaat dari penelitian ini adalah untuk (1) Menentukan penelitian lanjutan uji hedonik hasil jadi brownies menggunakan tepung gandum utuh atau "Whole Wheat Flour". (2) Memberikan pengetahuan tambahan yang berhubungan dengan penelitian Uji Hedonik hasil jadi brownies menggunakan tepung gandum utuh atau "Whole Wheat Flour".

\section{Landasan Teori}

\section{Gandum}

Menurut Ballard (2009), Gandum merupakan biji padi-padian yang memiliki nutrisi terbanyak dibandingkan biji padi-padian lainnya. Biji Gandum atau Wheat Kernel biasanya berbentuk lonjong seperti biji padi-padian lainnya. 


\section{Tepung Terigu}

Menurut Syarbini (2013), tepung terigu adalah hasil dari penggilingan biji gandum. Gandum merupakan salah satu tanaman biji-bijian yang biasa tumbuh di negara seperti Amerika, Kanada, Eropa, dan Australia. Secara umum tepung terigu biasa digunakan untuk membuat aneka macam makanan seperti kue dan roti. Hal ini menjadi salah satu dikonsumsi masyarakat karena dianggap sebagai pengganti karbohidrat dan praktik.

\section{Tepung Gandum Utuh}

Menurut Gisslen (2013), Whole Wheat Flour atau tepung gandum utuh merupakan tepung yang dihasilkan dari penggilingan keseluruhan biji gandum beserta Bran, Endosperm, dan Germ. Roti yang dibuat dengan $100 \%$ tepung gandum utuh lebih berat daripada roti yang terbuat dari $100 \%$ tepung terigu karena mengandung protein gluten yang lebih tinggi daripada tepung terigu. Adonan roti dengan $100 \%$ tepung gandum utuh biasanya lebih dipilih oleh masyarakat karena rasa yang kuat dan kandungan yang lebih sehat.

\section{Uji Organoleptik}

Menurut Waysima dan Adawiyah (2010), uji organoleptik atau evaluasi sensoris merupakan suatu pengukuran ilmiah dalam mengukur dan menganalisa karakteristik suatu bahan pangan yang diterima oleh indera penglihatan, pencicipan, penciuman, perabaan, dan menginterpretasikan reaksi dari akibat proses penginderaan yang dilakukan oleh manusia yang juga bisa disebut panelis sebagai alat ukur.

Dalam penelitian ini, penulis menggunakan uji kesukaan yang merupakan bagian dari uji organoleptik. Menurut Sofiah dan Achsyar (2008), uji kesukaan atau uji hedonik merupakan uji dimana panelis diminta memberi tanggapan secara pribadi tentang kesukaan atau ketidaksukaan beserta tingkatannya.

\section{METODE}

Desain penelitian yang dilakukan oleh penulis adalah penelitian dengan eksperimen. Menurut Siregar (2013), penelitian eksperimen (Eksperimental Research) merupakan penelitian yang dilakukan untuk memprediksi suatu fenomena, sehingga penulis dapat melakukan eksperimen pembuatan brownies dengan tepung gandum utuh.

Eksperimen yang dilakukan bertujuan untuk mencari tahu hasil jadi brownies yang dibuat menggunakan tepung gandum utuh dan perbandingan tingkat kesukaan hasil jadi eksperimen brownies yang menggunakan tepung gandum utuh dengan brownies yang menggunakan tepung terigu.

Penelitian eksperimen yang dilakukan adalah one-shot case study. One-shot case study adalah penelitian dimana terdapat suatu kelompok yang diberikan suatu perlakuan dan selanjutnya dilakukan observasi untuk mendapat suatu hasil. (Sugiyono, 2012).

Metode pengumpulan data yang digunakan dengan mengumpulkan data primer dan data sekunder. Data primer berasal dari kuisioner yang akan dibagikan kepada mahasiswa/i Hotel Management Binus University. Menurut Sugiyono (2012), kuisioner atau angket merupakan teknik pengumpulan data yang dilakukan dengan cara memberi seperangkat pertanyaan atau pernyataan tertulis kepada responden untuk dijawabnya, kuisioner bersifat efisien apabila peneliti mengetahui 
dengan pasti variabel yang akan diukur dan mengetahui apa yang bisa diharapkan dari responden. Untuk data sekunder, akan berasal dari buku-buku yang berhubungan dengan penelitian ini.

\section{Tempat Penelitian}

Penelitian dilakukan di BINUS University Kampus Anggrek yang beralamat di Jalan Kebon Jeruk Raya no. 27. Kebon Jeruk . Jakarta Barat, 11530, sebagai tempat pembuatan dan pengujian hedonic.

\section{Populasi Penelitian}

Menurut Sugiyono (2012), Populasi merupakan wilayah generalisasi yang terdiri atas objek/subjek yang mempunyai kualitas dan karakteristik tertentu yang ditetapkan oleh peneliti untuk dipelajari dan kemudian ditarik kesimpulannya. Populasi dalam penelitian ini adalah MahasiswaMahasiswi Binus University yang aktif.

\section{Sampel Penelitian}

Menurut Sugiyono (2012), sampel adalah bagian dari jumlah dan karakteristik yang dimiliki oleh populasi tersebut. Jika populasi besar dan peneliti tidak mungkin mempelajari semua yang ada pada populasi karena keternatasan dana, tenaga, dan waktu, maka peneliti dapat menggunakan sampel yang diambil dari populasi.

Menurut Sofiah dan Achyar (2008), bahwa berdasarkan tingkat sensitivitas dan tujuan dari setiap pengujian, dikenal beberapa macam panel yaitu panel ahli, panel terlatih, dan panel tidak terlatih. Jumlah minimal panelis yang harus diteliti oleh penulis adalah 80 panelis tidak terlatih, Sofiah dan Achyar (2008). Dalam penelitian ini penulis mengambil sampel dari mahasiswa-mahasiswi Binus University.

\section{Alat Ukur Penelitian dan Pengukuran}

Pada penelitian ini penulis akan menggunaan metode penelitian kuantitatif dengan instrument penelitian yaitu kuisioner. Menurut Sugiyono (2012), Metode Kuantitatif merupakan metode tradisional, karena metode ini sudah cukup lama digunakan sehingga sudah mentradisi sebagai metode penelitian. Metode ini disebut sebagai metode positivistik karena berlandaskan pada filsafat positivisme. Metode ini sebagai metode ilmiah karena telah memenuhi kaidah-kaidah ilmiah yaitu kongrit, obyektif, terukur, rasional, dan sistematis. Metode ini juga disebut metode konfirmatif, karena metode ini cocok digunakan untuk pembuktian atau konfirmasi.

Menurut Sugiyono (2012), skala pengukuran merupakan kesepakatan yang digunakan sebagai acuan untuk menentukan panjang pendeknya interval yang ada dalam alat ukur, sehingga alat ukur tersebut bila digunakan dalam pengukuran akan menghasilkan data kuantitatif. Dengan skala pengukuran, maka variabel yang diukur dengan instrument tertentu dapat dinyatakan dalam bentuk angka sehingga akan lebih akurat, efisien, dan komunikatif.

Dalam penelitian ini, skala yang digunakan penulis adalah enam skala hedonik yang merupakan skala hedonik seperti amat sangat suka, sangat suka, suka, agak suka, netral dan tidak suka (Sofiah dan Achsyar, 2008). 
Tabel 1 Skala Hedonik dengan Skala Numeriknya

\begin{tabular}{lc}
\hline \multicolumn{1}{c}{ Skala Hedonik } & Skala Numerik \\
\hline Amat Sangat Suka & 6 \\
Sangat Suka & 5 \\
Suka & 4 \\
Agak Suka & 3 \\
Netral & 2 \\
Tidak Suka & 1 \\
\hline
\end{tabular}

\section{Definisi Operasional Variabel Penelitian}

Menurut Sugiyono (2012), variabel penelitian pada dasarnya adalah segala sesuatu yang berbentuk apa saja yang ditetapkan oleh peneliti untuk dipelajari sehingga diperoleh informasi tentang hal tersebut, kemudian ditarik kesimpulannya. Pada penelitian ini penulis akan digunakan dua variabel, yaitu Operasionalisasi Variabel Tepung Terigu dan Operasionalisasi Variabel Tepung Gandum Utuh.

Menurut McKeon (2007), definisi Operasional Variabel Tepung Terigu adalah tepung terigu mengandung protein yang biasanya disebut gluten yang saat digabungkan dengan cairan maka dapat berubah menjadi elastis sehingga dapat membantu dalam pembuatan tekstur roti dan kue. Menurut Mutdani (2010), tepung terigu merupakan bahan utama dalam pembuatan roti yang terbuat dari penggilingan gandum sampai pemutihan. Protein dalam tepung akan mengikat air dan membentuk gluten yang dapat menahan gas karbondioksida pada saat fermentasi.

Menurut Wied Harry (2012), definisi operasional Variabel Tepung Gandum Utuh adalah tepung gandum utuh atau Whole Wheat Flour merupakan tepung dengan warna yang kecokelatan, karena mengandung kulit ari gandum dan tepungnya tidak mengalami proses pemucatan. Menurut Paula Figoni (2011), Whole Wheat Flour merupakan tepung dari hasil penggilingan campuran antara Bran, Endosperm, dan Germ yang tetap menjaga keutuhan keaslian kandungan dari biji gandum.

\section{Teknik Analisa Data}

Pada penelitian ini akan digunakan metode analisis statistik deskriptif. Menurut Sugiyono (2012), statistik deskriptif adalah statistik yang digunakan untuk menganalisa data dengan cara mendeskripsikan atau menggambarkan data yang telah terkumpul sebagaimana adanya tanpa bermaksud membuat kesimpulan yang berlaku untuk umum atau generalisasi. Dalam analisis deskriptif ini penyajian data dapat disajikan melalui tabel grafik, diagram lingkaran atau batang, dan pictogram.

Menurut Siregar (2013), uji paired T-test merupakan uji yang digunakan untuk mengetahui ada tidaknya perbedaan nilai rata-rata dua kelompok data yang berpasangan. Dalam penelitian ini, penulis membandingkan hasil jadi brownies dengan tepung terigu dan brownies dengan tepung gandum utuh. Alat hitung yang akan digunakan penulis untuk menghitung paired sample t-test adalah SPSS (Statistical Product and Service Solution). Dengan menggunakan SPSS, paired sample t-test akan menghasilkan nilai rata-rata (mean ) dan Sig.2-tailed untuk mengetahui signifikan produk yang diuji.

\section{Jenis Sumber Data}

Dalam penelitian ini penulis menggunakan sumber data primer dan juga sekunder. Menurut Sugiyono (2012) pengumpulan data dapat dilakukan dari berbagai setting, cara, dan sumber. Bila dilihat dari setting-nya data dapat dikumpulkan secara alamiah seperti pada laboratorium dengan 
metode eksperimen, sehingga bila dilihat dari datanya maka pengumpulan data dapat menggunakan sumber primer dan sumber sekunder. Sumber primer merupakan sumber data yang langsung memberikan data kepada pengumpul data dan sumber sekunder merupakan sumber data yang tidak secara langsung memberikan data kepada pengumpul data. Data primer penulis dapatkan dari hasil kuisioner yang diberikan kepada para panelis. Data sekunder dapat berupa dari buku-buku yang sudah banyak tercetak dipasaran.

\section{Teknik Pengumpulan Data}

Teknik yang digunakan untuk mengumpulkan data dalam penelitian ini adalah (1) Penelitian Kepustakaan; penelitian ini dilakukan untuk mengumpulkan data sekunder atau bahan yang bersifat teoritis dan relevan melalui buku, majalah, internet, dan lain-lain. (2) Penelitian Lapangan; penelitian ini bertujuan untuk memperoleh data secara langsung dari responden yang menjadi objek penelitian. Caranya dengan memberikan kuisioner. Menurut Sugiyono (2012), Kuisioner adalah teknik pengumpulan data yang dilakukan dengan memberikan atau menyebarkan seperangkat pertanyaan kepada responden untuk dijawab.

\section{HASIL DAN PEMBAHASAN}

\section{Panelis}

Menurut Betty dan Tjutju (2008), panelis merupakan orang-orang yang memiliki kelebihan sensorik yang dapat digunakan untuk menganalisa dan menilai karakteristik bahan pangan yang akan diteliti oleh penulis. Panelis terbagi dalam tiga jenis berdasarkan tingkat sensitivitas dan tujuan dari setiap pengujian, yaitu : (1) Panelis Ahli merupakan panel yang memiliki sensitivitas yang tinggi dan memiliki pengalaman dan latihan yang lama dalam mengukur dan menilai sifat karakteristik secara tepat. (2) Panelis Terlatih merupakan panel yang memiliki sensitivitas yang tidak setinggi panelis ahli tetapi merupakan pilihan dan seleksi yang kemudian menjalan pelatihan terus - menerus dan lolos pada evaluasi kemampuan. (3) Panelis Tidak Terlatih merupakan panel yang tidak berdasarkan sensitivitas namun untuk menguji tingkat kesenangan pada suatu produk atau tingkat kemauan untuk menggunakan suatu produk.

\section{Uji validitas}

Tabel 2 Uji Validitas Brownies A

Item-Total Statistics

\begin{tabular}{lrrrr}
\hline & $\begin{array}{c}\text { Scale Mean if } \\
\text { Item Deleted }\end{array}$ & $\begin{array}{c}\text { Scale Variance } \\
\text { if Item Deleted }\end{array}$ & $\begin{array}{r}\text { Corrected Item- } \\
\text { Total Correlation }\end{array}$ & $\begin{array}{c}\text { Cronbach's Alpha } \\
\text { if Item Deleted }\end{array}$ \\
\hline item1 & 22.91 & 16.840 & .323 & .685 \\
item2 & 22.14 & 15.487 & .437 & .647 \\
item3 & 21.39 & 14.873 & .494 & .626 \\
item4 & 23.08 & 17.488 & .248 & .705 \\
skortotal & 12.79 & 5.056 & 1.000 & .273 \\
\hline
\end{tabular}

Berdasarkan tabel 2 diatas, hasil dari Pearson Correlation menunjukkan nilai sebesar 0,220. Sehingga data dapat dikatakan valid karena nilai yang diperoleh lebih kecil dari 0,220. 
Tabel 3 Uji validitas Brownies B

Item-Total Statistics

\begin{tabular}{lrrrr}
\hline & $\begin{array}{c}\text { Scale Mean if } \\
\text { Item Deleted }\end{array}$ & $\begin{array}{c}\text { Scale Variance } \\
\text { if Item Deleted }\end{array}$ & $\begin{array}{c}\text { Corrected Item- } \\
\text { Total Correlation }\end{array}$ & $\begin{array}{c}\text { Cronbach's Alpha } \\
\text { if Item Deleted }\end{array}$ \\
\hline item1 & 32.40 & 11.458 & .261 & .672 \\
item2 & 32.84 & 10.821 & .321 & .653 \\
item3 & 32.49 & 11.443 & .358 & .645 \\
item4 & 32.21 & 10.549 & .419 & .619 \\
skortotal & 18.56 & 3.439 & 1.000 & .169 \\
\hline
\end{tabular}

Berdasarkan tabel 3 diatas, hasil dari Pearson Correlation menunjukkan nilai sebesar 0,220. Sehingga data dari aroma A dan aroma B dapat dikatakan valid karena nilai yang diperoleh lebih kecil dari 0,220 .

Tabel 4 Paired Sample T-Test

\begin{tabular}{|c|c|c|c|c|c|c|c|c|c|}
\hline \multicolumn{10}{|c|}{ Paired Samples Test } \\
\hline & & \multicolumn{5}{|c|}{ Paired Differences } & \multirow[b]{3}{*}{$t$} & \multirow[b]{3}{*}{$d f$} & \multirow[b]{3}{*}{ Big. (2-tailed) } \\
\hline & & & & & \multicolumn{2}{|c|}{$\begin{array}{c}95 \% \text { Confidence Internal of the } \\
\text { Difierence }\end{array}$} & & & \\
\hline & & Mean & Std Deviation & $\begin{array}{l}\text { Std. Error } \\
\text { Mean }\end{array}$ & Lomer & Upger & & & \\
\hline Pair 1 & rasa A-rasa $\mathrm{B}$ & -2.062 & 1.129 & .126 & -2314 & -1.811 & -16.340 & 79 & .000 \\
\hline Pair 2 & aroma a - aroma b & -.850 & 1.332 & .149 & -1.146 & -.554 & -5.707 & 79 & .000 \\
\hline Pair 3 & warna A - warna B & -.450 & 1.101 & .123 & -.695 & -.205 & -3.655 & 79 & .000 \\
\hline Pair 4 & Tekstur A - Tekstur B & -2.412 & 1.250 & .140 & -2.691 & -2.134 & -17.266 & 79 & 000 \\
\hline
\end{tabular}

Dari Hasil Paired Sample T-Test diatas, dapat dilihat bahwa pada subvariabel rasa brownies B lebih baik daripada brownies A. Dan signifikan subvariabel aroma brownies A dan brownies B adalah 0.00 dimana lebih kecil dibandingkan < sig 0,05, yaitu dapat disimpulkan bahwa H0 ditolak dan H1 diterima yaitu ada kesukaan rasa pada brownies menggunakan tepung gandum utuh.

Untuk subvariabel aroma, brownies B juga lebih baik dibandingkan brownies A dengan nilai signifikan subvariabel rasa brownies A dan brownies B dimana lebih kecil dibandingkan $<$ sig 0,05 sehingga $\mathrm{H} 0$ ditolak dan $\mathrm{H} 1$ diterima sehingga adanya kesukaan aroma pada brownies menggunakan tepung gandum utuh.

Untuk subvariabel warna, brownies B juga lebih baik dibandingkan brownies A dengan nilai signifikan subvariabel rasa brownies A dan brownies B dimana lebih kecil dibandingkan < sig 0,05 sehingga $\mathrm{H} 0$ ditolak dan $\mathrm{H} 1$ diterima sehingga adanya kesukaan warna pada brownies menggunakan tepung gandum utuh.

Sedangkan subvariabel tekstur, dimana brownies B lebih baik dibandingkan tekstur A dimana memiliki nilai signifikan yang lebih kecil dibandingkan < sig 0,05 sehingga H0 ditolak dan H1 diterima, yaitu adanya kesukaan tekstur pada brownies menggunakan tepung gandum utuh. 


\section{Statistik Mean Brownies}

Tabel 5 Paired Samples Statistics

\begin{tabular}{llrrrr}
\hline & & Mean & N & Std. Deviation Std. Error Mean \\
\hline Pair 1 & rasa A & 2.66 & 80 & .941 & .105 \\
& rasa B & 4.73 & 80 & .871 & .097 \\
Pair 2 & aroma a & 3.44 & 80 & 1.054 & .118 \\
& aroma b & 4.29 & 80 & .957 & .107 \\
Pair 3 & warna A & 4.19 & 80 & 1.092 & .122 \\
& warna B & 4.64 & 80 & .733 & .082 \\
Pair 4 & Tekstur A & 2.50 & 80 & .914 & .102 \\
& Tekstur B & 4.91 & 80 & .889 & .099 \\
\hline
\end{tabular}

Dilihat dari hasil diatas, dapat disimpulkan bahwa brownies B lebih unggul dibandingkan dengan brownies A karena seluruh aspek brownies B lebih tinggi dibandingkan dengan brownies A

\section{SIMPULAN}

Kesimpulan yang diperoleh secara keseluruhan dari uji kesukaan terhadap kue brownies yang menggunakan tepung terigu dan brownies yang menggunakan tepung gandum utuh adalah adanya kesukaan terhadap rasa, aroma, tekstur dan warna brownies yang menggunakan tepung gandum utuh. Dari kesimpulan diatas, dapat dikatakan bahwa ada daya terima masyarakat terhadap brownies yang menggunakan tepung gandum utuh dan brownies yang menggunakan tepung gandum utuh dapat menjadi alternatif lain dalam pembuatan brownies atau kue lainnya. Perlu dilakukan penelitian lebih lanjut mengenai pemakaian tepung gandum utuh dalam penggantian tepung dalam makanan agar dapat diketahui manfaat lain yang didapat jika mengganti tepung terigu dengan tepung gandum utuh.

\section{DAFTAR PUSTAKA}

Ballard, D. (2009). Master Bread Making Using Whole Wheat. (Cetakan ke-10). Springville : CFI.

Figoni, P. (2011). How Baking Works:Exploring The Fundamentals of Baking Sciences (Cetakan ke3). Kanada : John Wiley \& Sons.

Gisslen, W. (2013). Professional Baking (Cetakan ke-6). Kanada: John Wiley \& Sons.

McKeon, M.M. (2007). Crave a Passion For Chocolate. (Cetakan ke-1). China: 1010 Printing International.

Mutdani, H. (2010). Rahasia Membuat Roti Manis. (Cetakan ke-1). Jakarta: Agromedia Pustaka.

Siregar, S. (2013). Statistik Parametrik Untuk Penelitian Kuantitatif. (Cetakan ke-1). Jakarta: Bumi Aksara.

Sofiah, B. D., Achyar, T. S. (2008). Buku Ajar Kuliah Penilaian Indra. (Cetakan ke-1). Jatinangor: Universitas Padjadjaran. 
Syarbini, M. (2013). Referensi Komplet A-Z Bakery Fungsi Bahan, Proses Pembuatan Roti, Panduan Menjadi Bakepreneur (Cetakan ke-1). Solo: Tiga Serangkai Pustaka Mandiri.

Waysima, Adawiyah, Dede, R. (2010). Evaluasi Sensori (Cetakan ke-5). Bogor: Fakultas Teknologi Pertanian Institut Pertanian Bogor. 